\title{
The Impact of Surgical Site Infection to the Health Care Cost
}

\author{
Triani Marwati ${ }^{1}$, A. A. Subiyanto ${ }^{2}$, Totok Mardikanto ${ }^{3}$, Priyambodo ${ }^{4}$, \\ Marsiana Wibowo ${ }^{5}$, Nurul Qomariyah ${ }^{6}$ \\ ${ }^{1,5,6}$ Faculty of Public Health, Ahmad Dahlan University, Yogyakarta, Indonesia \\ ${ }^{2}$ Faculty of Medicine, University of Sebelas Maret, Surakarta, Indonesia \\ ${ }^{3}$ Faculty of Community Empowerment, University of Sebelas Maret, Surakarta, Indonesia \\ ${ }^{4}$ Clinical Pathology Department, Moewardi Hospital, Surakarta, Indonesia
}

\section{Article Info}

Article history:

Received Dec 26, 2015

Revised Mar 25, 2016

Accepted May 22, 2016

Keyword:

Cost treatment

Health care

Hospital

Infection operating area

Surgical site infection

\begin{abstract}
Surgical Site Infection (SSI) is the most common cause of nosocomial infections. The incidence of SSI is ranging between $14-16 \%$ of the entire incident of nosocomial infections in hospitalized patients. The objectives of this study were to determine the relationship between knowledge, attitude, infrastructure and behavior of health personnel to prevent SSI and to determine the amount of additional costs for hospital care as a result of SSI. This study used a mixed method research. Quantitative research conducted with descriptive analytic design with cross sectional approach. Quantitative data was analyzed by univariate and bivariate analysis. Qualitative research was used to measure additional cost due to SSI. Health personnel showed good knowledge about SSI prevention (89.6\%), good attitude towards SSI prevention (57\%), assessed good for hospital infrastructure (93.8\%), but only $55.2 \%$ showed good behavior to prevent SSI. There were no relationship between knowledge and attitudes of health personnel, and hospital infrastructure with health personnel behavior to prevent SSI. Additional cost due to SSI was IDR 18,375,000 for each patient.
\end{abstract}

Copyright (c) 201x Institute of Advanced Engineering and Science. All rights reserved.

\section{Corresponding Author:}

Triani Marwati,

Faculty of Public Health,

University of Ahmad Dahlan,

Jl. Prof Soepomo, Janturan, Warungboto, Yogyakarta - Indonesia

Email: triyanim@yahoo.com

\section{INTRODUCTION}

Surgical Site Infection (SSI) is an infection on surgical site or organ that occurred within 30 days post-surgery or within 1 year if there are implants. The source of infection can be derived from patient, doctor and team, the environment, and instrumentation [1]. SSI increased mortality and morbidity, extend the period of post-surgical treatment to two times longer and increase the cost of health care [2].

The incidence of SSI can reach $20 \%$, depend on the site of surgery, the criteria used for surveillance, and the quality of data collection. The reported incidence of SSI in the US is 2-5\%, Indonesia is 2-18\%, and in PKU Muhammadiyah Yogyakarta Hospital is 6\% [3]. The most common microorganisms are Staphylococcus aureus, coagulase-negative Staphylococci, Enterococcus spp. and Escherichia coli [2].

SSI prevention requires a series of efforts that are interconnected with each other: systematic concern to the number of risk factors to reduce the risk of bacterial contamination and to increase the patient's immune system. Guidelines issued by the Centers for Disease Control and Prevention emphasized the importance of good patient preparation, aseptic practices, attention to the surgical procedure; and antimicrobial therapy is indicated in some conditions [2].

PKU Muhammadiyah Yogyakarta and PKU Muhammadiyah Bantul Hospitals are two of several charitable efforts of Muhammadiyah organization in the health sector. PKU Muhammadiyah Yogyakarta was 
established in 1923 and run as type B hospital which has been accredited in 16 service areas. PKU Muhammadiyah Hospital Bantul was founded in 1966 and run as type C hospital with ISO 9001: 2008 certification, accredited by accreditation version 2012 from Indonesian Ministry of Health [4]. The team of Prevention and Control to Infection (PPI RS) in the hospital has been conducting several efforts to prevent SSI, but the data is not well documented. Patients and the hospital are also affected by the rising cost of health care due to SSI. Therefore, the authors was interested to investigate this issue. The objectives of this study were to determine the relationship between knowledge and attitude of health personnel, and hospital infrastructure, with behavior of health personnel to prevent SSI and to count additional cost due to SSI.

\section{RESEARCH METHOD}

This study was a mixed method research. Quantitative research was conducted with analytic descriptive design with cross sectional approach. Qualitative research was conducted to measure additional cost due to SSI.

The subjects of this study were health personnel who are associated with SSI prevention. The population was 653 people (from PKU Muhammadiyah Yogyakarta and Bantul Hospitals). The number of samples calculated by Slovin formula was 96 people. This research was conducted in August - September 2015.

Quantitative data was obtained by questionnaire. Validity and reliability of the instrument were done in type C hospital with 30 people as respondents, namely: medical doctors, nurses, staffs of surgery room, sanitarian, staffs of medical record, staffs of infrastructure and household. Validity test was done by testing the content validity, face validity, construct validity, and criterion validity. Validity measurement of each question was done by Pearson correlation technique, followed by t-test. Reliability test conducted for each variable in the questionnaire. Data was analyzed with univariate analysis to describe the characteristics of respondents. Bivariate analysis was done by Chi Square test. This test was done to determine the relationship between two variables (knowledge, attitudes, behavior of health personnel; and hospital infrastructure). Qualitative data was obtained from secondary data to determine additional cost due SSI.

\section{RESULTS AND ANALYSIS}

3.1. Quantitative Analysis

3.1.1. Characteristics of responden

Characteristics of the respondent can be seen in Table $1(n=96)$.

Table 1. Characteristics of the respondent

\begin{tabular}{cccc}
\hline & Respondent characteristics & Frequency & $\%$ \\
\hline \multirow{2}{*}{ Age } & $19-38$ years old & 69 & 36.5 \\
& 39-38 years old & 27 & 35.4 \\
Sex & Male & 17 & 17.7 \\
& Female & 79 & 82.3 \\
Education level & Senior High School & 6 & 63 \\
& (Diploma) D3/ D4 & 73 & 76.0 \\
\multirow{2}{*}{ Profession } & Undergraduate & 17 & 17.7 \\
& Nurse & 87 & 90.6 \\
Work & Health Analyze & 6 & 6.3 \\
experience & Midwive & 3 & 3.1 \\
\hline \hline
\end{tabular}

\subsubsection{Univariate analysis}

The result of univariate analysis of knowledge and attitude of health personnel, hospital infrastructure, and behavior of health personnel toward SSI prevention at PKU Muhammadiyah Yogyakarta hospital can be seen in Table 2 . 
Table 2. Knowledge, attitude, infrastructure, and behavior of health personnel toward SSI prevention at PKU Muhammadiyah Yogyakarta hospital

\begin{tabular}{cccc}
\hline Variables & Categories & Frequency & $\%$ \\
\hline \multirow{2}{*}{ Knowledge } & Not good & 10 & 10.4 \\
& Good & 86 & 89.6 \\
Attitude & Not good & 41 & 42.7 \\
& Good & 55 & 57.3 \\
Infrastructure & Well equipped & 6 & 6.3 \\
& Fairly equipped & 90 & 93.8 \\
Behavior & Not good & 43 & 44.8 \\
& Good & 53 & 55.2 \\
\hline
\end{tabular}

\subsubsection{Bivariate analysis}

The result of bivariate analysis between variables with Chi square can be seen in Table 3 .

Table 3. Chi Square test results

\begin{tabular}{lcccc}
\hline \multicolumn{1}{c}{ Variables } & P value & Lower & Upper & PR \\
\hline The relationship between knowledge and behavior to prevent SSI & 0.042 & 1.316 & 2.937 & 1.966 \\
The relationship between attitude and behavior to prevent SSI & 0.235 & 0.445 & 1.161 & 0.719 \\
The relationship between infrastructure and behavior to prevent SSI & 0.124 & 1.282 & 3.040 & 1.974 \\
\hline
\end{tabular}

\subsubsection{The relationship between knowledge and behavior to prevent SSI}

The results of Chi Square test showed $\mathrm{p}$ value $=0.042(\mathrm{p}<0.05)$. It showed that there was a significance relationship between knowledge and behavior to prevent SSI. Andrew FS stated that the level of education is a long term process with systematic and organized structure [3]. Managerial staff will learn conceptualized knowledge and theory for general purpose. Majority of respondent in this study had diploma education background as a nurse. Diploma education level is a study that emphasized on skills. In providing medical services to the patient, a well skilled nurse is needed, including post surgery rehabilitation. Good skills must be supported with good knowledge.

Educational programs developed for surgeons showed significant improvement to prevent SSI. Pre surgery duration and time of prophylactic antibiotics administration have a significant relationship with the SSI incidence [5]. The nurses must have a good knowledge about SOP and what to achieve for each procedure that will be done. They will have more self confident by applying the SOP properly. SOP serves as guidelines, communications tools and controlling, and the work can be completed consistently [6].

\subsubsection{The relationship between attitude and behavior to prevent SSI}

The results of Chi Square showed $\mathrm{p}$ value $=0.235(\mathrm{p}>0.05)$. It showed that there was no significance relationship between attitude and behavior to prevent SSI. The results of this study also show different result with previous study conducted by Herpan \& Wardani [7]. Herpan study showed significant relationship between attitude and behavior to control nosocomial infection in the hospital.

The principle of enhanced recovery after surgery (ERAS) could be implemented effectively if there are good collaboration between patient and health care provider. Therefore postoperative recovery is not the responsibility of health care providers entirely, but the patients also can participate actively by increasing nutrients to improve the recovery of surgical wound [5].

\subsubsection{The relationship between infrastructure and behavior to prevent SSI}

The results of Chi Square showed $p$ value $=0.124$ ( $>>0.05)$. It showed that there was no significance relationship between infrastructure and behavior to prevent SSI. The study showed that $93.8 \%$ of health personnel assessed infrastructures available to prevent SSI are well equipped. A person's behavior may appear based on the stimulus presented to the person. Several factors that support the realization of behavior are: knowledge and attitude of health personnel, and infrastructure availability. WHO in 2011 suggested that the availability of resources is one of the factors that support a person behavior. Infrastructure is one of the sources that can influence behavior positively or negatively [8]. Majority of health personnel in this study (93.8\%) stated that PKU Muhammadiyah Yogyakarta and Bantul hospitals were well equipped to prevent SSI.

SOR (Stimulus Organism Response) theory explained that a person will behave based on the stimulus he/she received. A person will react based on the stimulus and the stimulus in this study was the hospital infrastructures. However, this study showed that good score for infrastructure showed no relationship with

The Impact of Surgical Site Infection to the Health Care Cost in Yogyakarta Hospital (Triyani Marwati) 
the behavior to prevent SSI. Behavior is a defence mechanism, and in this context it means a defense mechanism to respond environment threats (noscomial infection), especially SSI [9]. Green \& Kreuter in 2008 stated that the implemented policy is one of the factors that support the emergence of the behavior. Assertiveness on the policy implementation to prevent SSI is needed. Assertive regulation is an external factor from behavior. Even though the health personnel showed attitude that does not support SSI prevention, the assertive regulation will support the health personnel to implement the regulation [10].

\subsection{Qualitative Analysis}

Based on the health care cost calculation, a patient must pay IDR 18,375,000 as additional cost due to SSI. Cost calculation on sectio caesarea (SC) without complication can be seen in Table 4 .

Table 4. Cost calculation difference between SC without SSI and SC with SSI

\begin{tabular}{lcc}
\hline \multicolumn{1}{c}{ Description } & SC without SSI (IDR) & SC with SSI (IDR) \\
\hline Medical services from obstetrics and gynecologist & $1,000,000$ & $8,500,000$ \\
Medical services from anesthesiologist & 400,000 & $3,400,000$ \\
Equipment sterillization & 180,000 & $1,530,000$ \\
Direct resource overhead & 870,000 & $7,395,000$ \\
Total & $2,450,000$ & $20,825,000$ \\
Difference & & $18,375,000$ \\
\hline
\end{tabular}

The incidence of SSI was ranged $14-16 \%$ of nosocomial infection in hospitalized patient. SSI occurred every year and is associated with longer duration of post surgery health care for 7-10 days (mean=8.5 days). Patients with SSI have 2-11 times higher for death compare to patients without SSI. Additional cost related to SSI is varied, depend on the kind of surgery procedure and infected pathogen. But the estimated cost due to SSI reached to \$10 billion a year [11].

The incidence of SSI in Indonesia from previous study is varied between 2-18\% from all the surgery procedure and $2 \%$ from appendectomy. Meanwhile the SSI incidence in PKU Muhammadiyah Yogyakarta in 2012 was 6\% from all nosocomial infection that was occurred in PKU Muhammadiyah Yogyakarta hospital [12].

\section{CONCLUSION AND RECOMMENDATION}

\subsection{Conclusion}

There was a significance relationship between knowledge and behavior to prevent SSI. There was no significance relationship between attitude and behavior, infrastructure and behavior to prevent SSI. Additional cost due to SSI is IDR 18,375,000 for each patient.

\subsection{Recommendation}

Hospital management should provide appropriate methods to increase knowledge (by training) of health personnel to change their attitudes and behavior toward SSI prevention. Socialization is needed for infrastructure compliance by appropriate socialization how to use the new equipment, in order to change health personnel behavior in using the equipment.

Hospital management should consider about patient safety and risk management in every effort especially the impact of infection. Optimizing the roles of Infection Control Committee (Komite Pengendalian Infeksi) to supervise and monitor the potential incidence of infection in the hospital.

\section{REFERENCES}

[1] Hidayat, "Nursing Research Methods and Data Analysis Techniques (Metode Penelitian Keperawatan dan Teknik Analisa Data),” Jakarta, Salemba Medika, 2009.

[2] C. D. Owen \& K. Stoessel, "Surgical site infections: epidemiology, microbiology and prevention," Journal of Hospital Infection, vol/issue: 70(S2), pp. 3-10, 2008.

[3] Mangkunegara, \& A. A. A. Prabu, "Company Human Resource Management (Manajemen Sumber Daya Manusia Perusahaan), Bandung, PT. Remaja Rosdakarya, 2003.

[4] Rumah Sakit PKU Muhammadiyah Bantul, “General data (Data Umum)," 2015. Available at http://www.rspkubantul.com/hal-data-umum.html diakses pada 9 Oktober 2015.

[5] F. Rivai, et al., "Determinant of Surgical Site Infection Post-section Caesarea," Jurnal Kesehatan Masyarakat

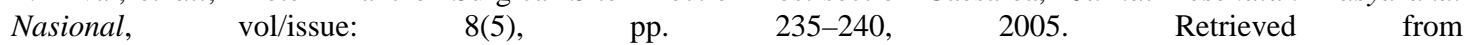
http://jurnalkesmas.ui.ac.id/index.php/kesmas/article/download/390/389. 
[6] S. M. McHugh, et al., "Preventing infection in general surgery: improvements through education of surgeons by surgeons,” Journal of Hospital Infection, vol/issue: 78(4), pp. 312-316, 2011.

[7] Herpan \& Y. Wardhani, "Analysis of the nurse's performance in nosocomial infection comtrol at Bantul PKU Muhammadiyah hospital Yogyakarta (Analisis kinerja perawat dalam pengendalian infeksi nosokomial di RSU PKU Muhammadiyah Bantul Yogyakarta),” Jurnal Kesmas, vol/issue: 6(3), 2012.

[8] World Helath Organization, "Clean Care is Safer Care Team. Report on theburden of endemic health careassociated infection worldwide," Geneva, World HealthOrganization Press, 2011.

[9] Maulana \& D. J. Heri, “Health promotion (Promosi Kesehatan),” Jakarta, Penerbit Buku Kedokteran EGC, 2009.

[10] L. W. Green \& M. W. Kreuter, "Health Promotion Planning: An Educational and Enviromental Approach. Second Edition,” Mayfield Publishing Company, USA, pp. 30, 2008.

[11] D. J. Anderson, et al., "Strategies to prevent surgical site infections in acute care hospitals," Infect Control Hosp Epidemiol, vol. 1, pp. S51-61, 2008.

[12] N. Supiana, "Implementation and Assessment of the use of PPE by doctors and midwives in maternity and postpartum room PKU Muhammadiyah Yogyakarta hospital Unit I," (Pelaksanaan Kebijakan dan Penilaian Penggunaan APD oleh Dokter dan Bidan di Ruang Bersalin dan Nifas RSU PKU Muhammadiyah Yogyakarta Unit I), 2015. 